\title{
A comparative study of PPIUCD acceptance between primiparaous and multiparaous women in a tertiary care hospital in Tamil Nadu
}

\author{
K. S. Ramya, T. S. Meena, R. Mothilal*
}

Department of Family Welfare, Government Kilpauk Medical College Hospital, Chennai, Tamil Nadu, India

Received: 06 June 2017

Accepted: 29 June 2017

\section{*Correspondence:}

Mr. R. Mothilal,

E-mail: mothilal15661@gmail.com

Copyright: () the author(s), publisher and licensee Medip Academy. This is an open-access article distributed under the terms of the Creative Commons Attribution Non-Commercial License, which permits unrestricted non-commercial use, distribution, and reproduction in any medium, provided the original work is properly cited.

\begin{abstract}
Background: Postpartum intrauterine contraceptive device (PPIUCD) is a postpartum family planning method which provides spacing to the next pregnancy and also it helps to avoid unwanted / unintended pregnancy during postpartum period. Our aim is to study the willingness and PPIUCD acceptance between primiparaous and multiparaous women and compare them as a factor of route of insertion (vaginal versus caesarean).

Methods: 1060 vaginal and caesarean deliveries conducted over a period of three months and 676 PPUCD insertions was done among the deliveries in a tertiary care hospital. A comparative cross-sectional study was done on the acceptance of PPIUCD by postpartum mothers between primiparous and multipararous women among the deliveries for the study period.

Results: The proportion of willingness for PPIUCD was $68.8 \%$ among the postpartum mothers. The percentage of acceptance of PPIUCD was $73.8 \%$ and $51.4 \%$ in respect of primiparous and multiparous postpartum mothers. The route of PPIUCD insertion was more in caesarean deliveries $(34.1 \%)$ than in vaginal deliveries $(29.7 \%)$ in the total deliveries. The PPIUCD insertion in primiparous women was effective and statistically significant at p-value is $<0.05$. Conclusions: PPIUCD is a strong weapon in the family planning and should be encouraged in both vaginal and caesarean deliveries. The acceptability of PPIUCD by postpartum mothers was more in primiparous than in multiparous women.
\end{abstract}

Keywords: Acceptance, Postpartum, Willingness

\section{INTRODUCTION}

Contraception methods mean to prevent unwanted pregnancy by temporarily or permanently. Intrauterine contraceptive device like CuT- 380A provides contraception up to 10 years. ${ }^{1}$ India is the second largest populated country in the world with 120 million according to 2011 census. $^{2}$ It contributes $17.5 \%$ of world's population by adding around 25 million births every year. ${ }^{3}$ A $65 \%$ of women are having unmet need of family planning in the first year of post-partum period. ${ }^{3}$ Till 2 years after delivery, a woman will not be ready physically to conceive and delivery. Studies were found that conceiving within two years leads to adverse events like abortion, premature labour, postpartum haemorrhage, low birth weight babies, foetal loss sometimes maternal deaths. Hence advising and practicing contraception within postpartum period is good for women health. ${ }^{4}$ Intra uterine contraceptive device is the most commonly used reversible method of contraception worldwide with about 127 million current users. ${ }^{5}$

The objective of the study was to assess the proportion of willingness for PPIUCD among postpartum mothers who attended to obstetric ward for delivery in a tertiary care hospital. To determine the independence of the attributes 
that PPIUCD insertions among postpartum mothers according to the number of living children and mode of delivery in a tertiary care hospital. To assess the percentage of acceptance of PPIUCD among the postpartum mothers according to their parity who attended obstetric ward for delivery in a tertiary care hospital.

\section{METHODS}

All the women who attended ante natal care visits and at the time admission that is before delivery were sensitized about advantages and importance of family planning methods.

Advantages of postpartum intrauterine contraceptive device and complications were explained. A comparative cross-sectional hospital based analytical study was conducted to 676 women who had postpartum intrauterine contraceptive device insertion including the deliveries for the period from January 2017 to March 2017 in the Government Kilpauk Medical College and Hospital, Chennai-10. The data obtained from the PPIUCD register and Parturition Register were used as a secondary data. ${ }^{6}$ Ratio, Proportion, Percentage, Z-test and Chi-square test were used for statistical analysis. Statistical software used.

\section{Statistical analysis}

\section{Hypothesis I}

Ho: The proportion of willingness for postpartum intrauterine contraceptive device by postpartum mothers who attended to obstetric ward for delivery was $=50 \%$.

H1: The proportion of willingness for postpartum intrauterine contraceptive device by postpartum mothers who attended to obstetric ward for delivery was $\neq 50 \%$.

Formula: $\mathrm{Z}=\mathrm{P} 1-\mathrm{P} 0 / \sqrt{ } \mathrm{PQ} / \mathrm{N}$

Where P1 is the proportion stated in the sample, PO is the proportion stated in the null hypothesis; $\mathrm{N}$ is the sample size and $\mathrm{Q}=1-\mathrm{P} 0$.

\section{Calculation}

$\mathrm{P} 1=729 / 1060=0.68774 ; \mathrm{P} 0=50 \%=0.50$

$\mathrm{Z}=0.68774-0.50 / 0.01852=10.13714$ and $\mathrm{P}$ value $=<$ 0.00001

Since the calculated absolute $\mathrm{z}$ value $|10.13714|$ is greater than 1.96 at $(0.05)$ level of significance, we can reject the null hypothesis.

Therefore, $68.8 \%$ of women showing willingness for postpartum intrauterine contraceptive device after delivery was correct and statistically significant since pvalue is $<0.00001$.

\section{Hypothesis II}

Ho: The attributes, PPIUCD insertion among the postpartum mothers according to the number of children who attended to obstetric ward for delivery and mode of delivery are independent

H1: The attributes, PPIUCD insertion among the postpartum mothers according to the number of children who attended to obstetric ward for delivery and mode of delivery are not independent.

Table 1: Mode of delivery versus PPIUCD insertion in primiparaous women.

\begin{tabular}{|llll|}
\hline $\begin{array}{l}\text { Mode of } \\
\text { delivery }\end{array}$ & Accepted & Not accepted & Total \\
\hline $\begin{array}{l}\text { Vaginal } \\
\text { delivery }\end{array}$ & $203(34.6 \%)$ & $36(6.1 \%)$ & $\begin{array}{l}239 \\
(40.7 \%)\end{array}$ \\
\hline $\begin{array}{l}\text { Caesarean } \\
\text { section }\end{array}$ & $230(39.2 \%)$ & $118(20.1 \%)$ & $\begin{array}{l}348 \\
(59.3 \%)\end{array}$ \\
\hline Total & $433(73.8 \%)$ & $154(26.2 \%)$ & $\begin{array}{l}587 \\
(100.0 \%)\end{array}$ \\
\hline
\end{tabular}

There exist an association in relation between acceptance, non-acceptance of PPIUCD insertion and mode of delivery that vaginal and caesarean section among the primiparous women.

Since the calculated chi-square value 26.0 is greater than the chi-square table value 3.84 , the null hypothesis can be rejected and hence the alternative hypothesis that the attributes, PPIUCD insertion with primiparous women and mode of delivery were not independent and was statistically significant at $p$-value is $<0.05$ and d.f. $=1$.

Table 2: Mode of delivery versus PPIUCD insertion in multiparaous women.

\begin{tabular}{|llll|}
$\begin{array}{l}\text { Mode of } \\
\text { delivery }\end{array}$ & Accepted & Not accepted & Total \\
$\begin{array}{l}\text { Vaginal } \\
\text { delivery }\end{array}$ & $112(23.7 \%)$ & $93(19.6 \%)$ & $\begin{array}{l}205 \\
(43.3 \%)\end{array}$ \\
\hline $\begin{array}{l}\text { Caesarean } \\
\text { section }\end{array}$ & $131(27.7 \%)$ & $137(29.0 \%)$ & $\begin{array}{l}268 \\
(56.7 \%)\end{array}$ \\
\hline Total & $243(51.4 \%)$ & $230(48.6 \%)$ & $\begin{array}{l}473 \\
(100.0 \%)\end{array}$ \\
\hline
\end{tabular}

There exist no association in relation between acceptance, non-acceptance of PPIUCD insertion and mode of delivery that vaginal and caesarean section among the multiparaous women since chi-square value is 1.5392 .

Since the calculated chi-square value 1.5392 is less than the chi-square table value 3.84 , the null hypothesis may be accepted and hence that the attributes, mode of delivery and postpartum intrauterine contraceptive device insertion in women with 2 and more children after delivery were independent. 


\section{Hypothesis III}

Ho: The percentage of PPIUCD acceptance by postpartum mothers between primiparous and multiparaous women are equal.

H1: The percentage of PPIUCD acceptance by postpartum mothers between primiparous and multiparaous women are not equal.

Table 3: PPIUCD vs parity wise postpartum mothers.

\begin{tabular}{|llll|}
\hline PPIUCD & Primi & Multi & Total \\
\hline Accepted & 433 & 243 & 676 \\
\hline Not accepted & 154 & 230 & 384 \\
\hline Total & 587 & 473 & 1060 \\
\hline
\end{tabular}

There exist an association in relation between PPIUCD acceptance, non-acceptance and Postpartum mothers according to their parity since p-value is $<0.05$ with d.f. $=1$.

Since the calculated chi-square value 56.8411 is greater than the chi-square table value 3.84 , the null hypothesis can be rejected and hence the alternative hypothesis that the there was a difference between the acceptance of PPIUCD and the postpartum mothers according to their parity and statistically significant since p-value is $<0.05$ with degrees of freedom $=1$.

\section{RESULTS}

In present study, total number of women who have delivered from January 2017 to March 2017 accounted to 1060, out of which $55.4 \%$ were primiparaous and $44.6 \%$ were multiparaous deliveries respectively.

Table 4: Mode of delivery versus awareness.

\begin{tabular}{|llll|}
\hline Mode of Delivery & Nos. & A wareness & $\%$ \\
\hline Vaginal Delivery & 444 & 344 & 32.5 \\
\hline Caesarean section & 616 & 433 & 40.8 \\
\hline Total & 1060 & 777 & 73.3 \\
\hline
\end{tabular}

In present study $73.3 \%$ of women were aware of postpartum intrauterine contraceptive device. The willingness of postpartum intrauterine contraceptive device was $68.8 \%$ in women and statistically significant. The proportion of the women had postpartum intrauterine contraceptive device insertion with primiparaous, multi paraous and in both combined were $40.8 \%, 23.0 \%$ and $63.8 \%$ respectively. The acceptance and non-acceptance was nearly 3:1 ratio in respect of primiparaous women. Similarly, it was almost 1:1 for multiparaous women. It was found that PPIUCD insertion was more in caesarean deliveries than in vaginal deliveries by postpartum mothers between primiparaous and multiparaous women. Similarly, the non-acceptance of PPIUCD in caesarean section was more than in vaginal delivery was noticed. The postpartum intrauterine contraceptive device acceptance in primiparous women $(73.8 \%)$ was higher than in multiparaous women $(51.4 \%)$ who attended for delivery in a tertiary care hospital. The Table 4 shows $73.3 \%$ of women were aware of postpartum intrauterine contraceptive device immediately after delivery.

Table 5: Mode of delivery versus willingness.

\begin{tabular}{|c|c|c|c|c|}
\hline \multirow{2}{*}{$\begin{array}{l}\text { Mode of } \\
\text { delivery }\end{array}$} & \multirow{2}{*}{ No. } & \multicolumn{3}{|c|}{ Willingness in } \\
\hline & & Primi & Multi & Total \\
\hline $\begin{array}{l}\text { Vaginal } \\
\text { delivery }\end{array}$ & 444 & $\begin{array}{l}210 \\
(19.8 \%)\end{array}$ & $\begin{array}{l}112 \\
(10.6 \%)\end{array}$ & $\begin{array}{l}322 \\
(30.4 \%)\end{array}$ \\
\hline $\begin{array}{l}\text { Caesarean } \\
\text { section }\end{array}$ & 616 & $\begin{array}{l}276 \\
(26.0 \%)\end{array}$ & $\begin{array}{l}131 \\
(12.4 \%)\end{array}$ & $\begin{array}{l}407 \\
(38.4 \%)\end{array}$ \\
\hline Total & 1060 & $\begin{array}{l}486 \\
(45.8 \%)\end{array}$ & $\begin{array}{l}243 \\
(23.0 \%)\end{array}$ & $\begin{array}{l}729 \\
(68.8 \%)\end{array}$ \\
\hline
\end{tabular}

The Table 5 shows $68.8 \%$ of women were willing for postpartum intrauterine contraceptive device immediately after delivery. It reveals that the willingness for PPIUCD namely in primiparaous and multiparaous women are $45.8 \%$ and $23.0 \%$ respectively.

Table 6: Mode of delivery versus acceptance.

\begin{tabular}{|lllll|}
\hline $\begin{array}{l}\text { Mode of } \\
\text { delivery }\end{array}$ & \multirow{2}{*}{ No. } & $\begin{array}{l}\text { Acceptance with } \\
\text { Primi }\end{array}$ & Multi & Total \\
\hline $\begin{array}{l}\text { Vaginal } \\
\text { delivery }\end{array}$ & \multirow{2}{*}{444} & $\begin{array}{l}203 \\
(19.1 \%)\end{array}$ & $\begin{array}{l}112 \\
(10.6 \%)\end{array}$ & $\begin{array}{l}315 \\
(29.7 \%)\end{array}$ \\
\hline $\begin{array}{l}\text { Caesarean } \\
\text { section }\end{array}$ & \multirow{2}{*}{616} & $\begin{array}{l}230 \\
(21.7 \%)\end{array}$ & $\begin{array}{l}131 \\
(12.4 \%)\end{array}$ & $\begin{array}{l}(361 \\
(34.1 \%)\end{array}$ \\
Total & \multirow{2}{*}{1060} & $\begin{array}{l}433 \\
(40.8 \%)\end{array}$ & $\begin{array}{l}243 \\
(23.0 \%)\end{array}$ & $\begin{array}{l}676 \\
(63.8 \%)\end{array}$ \\
\hline
\end{tabular}

The Table 6 shows the proportion of women $(63.8 \%)$ were accepted postpartum intrauterine contraceptive device immediately after delivery. It reveals that the proportion of acceptance for postpartum intrauterine contraceptive device namely in primiparaous and multiparaous women are $40.8 \%$ and $23.0 \%$ respectively and the route of acceptance of postpartum intrauterine contraceptive device is more in caesarean section (34.1\%) than in vaginal delivery $(29.7 \%)$.

\section{DISCUSSION}

\section{Willing to use a FP Method}

Demographic and Health Survey shows that 40 percent of women in the first year postpartum intend to use a family planning (FP) method. ${ }^{3}$ In the present study, it was $68.8 \%$. The most common reasons behind it was study setting.

\section{Acceptability}

PPIUCD acceptance $42.15 \%$ in primipara and $57.85 \%$ in multipara were found in the study conducted in MLB medical college, Jhansi, Uttar Pradesh, India by Sushila 
Kharkwal, Sanjaya Sharma and Dr.Kumari Manisha.? The findings were reflected in the study conducted by Kanmani K, Gokulakrishnan G, Rani PR in Vellore Medical College, Tamil Nadu where it was found that PPIUCD acceptance $87.8 \%$ in primipara and $45.3 \%$ in multipara. ${ }^{9}$ In the present study, the acceptance of PPIUCD was significantly higher in primiparaous $(73.8 \%)$ than in multiparaous $(51.4 \%)$. The most common reasons behind it was PPFP counselling $(82.8 \%)$ day by day by RMNCH to make the women for willing to accept PPIUCD and awareness of paturients (91\%) in primiparaous and monthly review meeting conducted by the state officials.

\section{Mode of delivery}

In the study conducted by Sangeetha Jairaj, Sridhar Dayyala, it found that $43.9 \%$ of PPIUCD accepted who were underwent caesarean section and it was $6.3 \%$ in vaginal delivery were found. ${ }^{10}$ In the present study the PPIUCD acceptance was $34.1 \%$ and $29.7 \%$ in caesarean and vaginal delivery respectively.

\section{CONCLUSION}

In the present study, the postpartum contraceptive intrauterine device acceptance among the primiparaous women was higher than in multiparaous women and statistically significant at $\mathrm{p}$-value is $<0.05$.

The acceptance of PPIUCD in multiparaous women was comparatively low because of needs for permanent method in women with 2 and more children. The nonacceptance of PPIUCD among postpartum mothers who gave child birth through the route of caesarean section was higher than in vaginal delivery with primiparaous women was found in the study. Hence, efforts should be made to educate the public about safety, proper usage and convenience of modern, long-term, reversible methods of contraception. Health care personnel should also counsel the clients for adopting the contraceptives according to their need.

Funding: No funding sources Conflict of interest: None declared Ethical approval: Not required

\section{REFERENCES}

1. Park K. social and preventive medicine. $23^{\text {rd }}$ ed. Jabalpur Banarsidas bhanot; 2015.

2. Census organization of India, 2011. Ln: India at Glance - Population census; 2011. Available at: http://censusindia.gov.in/2011-prov-results/india at glance. html.

3. Ministry of Health and Family Welfare, Family Planning Division, Government of India, New Delhi. Ln: Post-partum IUCD reference manual; 2010.

4. Kanhere A, Pateriya P, Jain M. Acceptability and Feasibility of Immediate postpartum IUCD insertion in a tertiary care centre in Central India. Internat $\mathbf{J}$ Reproduct Contracept Obstetr Gynecol. 2015;4(1):1.

5. Nelson A. Gynaecology and Obstetrics. In: 2. Intrauterine contraceptives, vol. 6 .

6. In: Deliveries and PPIUCD Acceptors for the reference period from 1st January to 31st March. Chennai-10; 2017.

7. Kharkwal S, Sharma S, Kumari M. A comparative study of postpartum intrauterine contraceptive device acceptance between primiparaous and multiparous women in a tertiary care centre. IJRCOG. 2016;5(7):2304-6.

8. Shukla M, Qureshi S, Chandrawati. Post-placental intrauterine device insertion - A five-year experience at a tertiary care centre in North India. Indian Journal of Medical Research. 2012;136(3):432-35.

9. Kanmani K, Gokulakrishnan G, Rani P.R. Acceptance of postplacental intrauterine contraceptive device: recent increase in trend. IJRCOG. 2016;5(5):1341-4.

10. Jairaj S, Dayyala S. A cross sectional study on acceptability and safety of IUCD among postpartum mothers at tertiary care hospital, Telangana. JCDR. 2016;10(1):LC01.

Cite this article as: Ramya KS, Meena TS, Mothilal R. A comparative study of PPIUCD acceptance between primiparaous and multiparaous women in a tertiary care hospital in Tamil Nadu. Int J Reprod Contracept Obstet Gynecol 2017;6:3569-72. 